\title{
瀬戸内地方の採石場における花崗岩質岩石の異方性
}

\section{ANISOTROPY OF GRANITIC ROCK IN THE INLAND SEA IN WESTERN JAPAN}

\author{
工藤洋三*・橋本堅一**・佐野 修***・中川浩二****
}

By Yozo KUDO, Ken-ichi HASHIMOTO, Osam SANO and Köi NAKAGAWA

\begin{abstract}
In situ orientation of the three planes of anisotropy in granite was at first investigated with the empirical aid of quarrymen at twenty-six quarries in the Inland Sea area in Western Japan. The azimuthal variation of the sound velocity was measured and the feature of the cracks was investigated on thin sections of the rock with an optical microscope. The defects were classified into open cracks, healed cracks and other defects for every rock. In the specimens from almost all of the quarries, the rift plane consists of open cracks within the quartz's grains and the strikes are nearly parallel to the horizontal plane. Thus the grain plane and the hardway plane is vertical. The grain plane consists of open cracks and/or healed ones within the quartz, while the hardway plane consists of a few cracks within the quartz but often consists of healed cracks within the feldspar grain.
\end{abstract}

Keywords : granitic rock, anisotropy, crack, microscopy

\section{1.はじめに}

花崗岩質岩石の 1 つの構造的特徴として, 岩石内に選 択的な配列方向を有する微小欠陥構造がある。この微小 欠陥構造の選択的配向性は，原位置岩盤あるいは岩石供 試体の力学的性質の異方性の原因となる．このため原位 置試験や室内試験において, 実験結果の解釈にこれらの 微小欠陥構造の異方性を考慮する必要が生じてくる. し かし花崗岩質岩石の岩石組織は地域的に異なる特徵を もっており，花崗岩質岩石の一般的な特徵を解明しよう とする場合，局所的な特徵だけでなく広域的な特徵を明 らかにしておくことがその試験結果を解釈するうえにし ばしば有用な情報となり得る．本研究は，瀬戸内地方の 花崗岩質岩石の欠陥構造の原位置での方向性を明らかに するとともに，岩石内部の微小欠陥構造を分類し，微小 欠陥構造の局所的な特徵と広域的な特徴について検討す ることを目的としている.

花崗岩質岩石の異方性に関する研究が数多く報告され ているが, 初期の研究は地質学的な立場からこの問題を

* 正会員 工修 徳山工業高等専門学校助教授 （７45 徳山市久米字高城 3538）

** 正会員 徳山工業高等専門学校講師 (同上)

*** 正会員 工博 山口大学助手 工学部

**** 正会員 工博 山口大学教授 工学部
扱ったものが多( ${ }^{1)-3)}$. たとえば Dale ${ }^{1)}$ は，New England 地方の花崗岩質岩石を調査し，花崗岩質岩石の性 質がほぼ直交異方性を示すと述べている．またこれらの 直交異方性は割れやすい 2 つ面で特徴づけられてお り，それらはその順に rift plane, grain plane ${ }^{\ddagger 2)}$ とよば れ，さらに両者に直交する面は hardway plane ${ }^{\text {iz2) とよ }}$ ばれている．本研究においても以下この表記法に従う。 また最近ではこの微小久陥構造と地圧とを関連させた研 究がみられる．たとえば Plumbら $(1984)^{4)}$ は, New England の 3 加所の採石場の花崗岩質岩石の地圧の測 定と $V_{\boldsymbol{p}}$ の測定を行い, さらに室内における岩石供試体 の $V_{\rho}$ の測定, 薄片の観察などを行って, クラックの選 択的配向性と原位置地表面近傍での初期応力との関連に ついて論じている。

著者らは, 大島 (伊予大島) 産の花崗閃緑岩を用いて, 岩石供試体の弾性波速度試験および圧裂強度試験を行

注 1）本研究では花崗岩質岩石の強度低下や力学的性質に異 方性をもたらす造岩鉱物内の構造を総称して微小久陥構 造とよぶ.

注 2）花崗岩質岩石は採石の際に割れやすい面を有しており それらの面はほぼ直交している。採石場ではこれらの割 れやすい面を，石目あるいは単に目とよんでいる. わが 国の採石場では，割れやすい順に，目，二番，シワなよ゙ とよばれており，これに対応する英語圈での表現が rift plane, grain plane, hardway plane である. 
い，こうした花崗岩の力学的特性とクラックなど微小欠 陷構造との関連について明らかにした ${ }^{5)}$. 大島産の花崗 閃緑岩の場合は，rift plane，grain plane を特徵づける ものが主として開ロしたクラック衫3であり, hardway plane を特徴づける構造は長石内の液粒面 ${ }^{\text {流 }}$ の選択的な 配向であった。この岩石を用いた圧裂試験の結果は，採 石場における経験則の洗練性を立証する結果となり，同 時に hardway plane にも長石内に微小久宿構造の選択 的な配向性が認められることを明らかにした．また現在 の石目の方向と斜交する石英粒内の液粒面の系について も言及しておいた。

これらの研究から，花崗岩質岩石の石目を特徵づける ものが，クラックや夜粒面など微小欠陥構造の選択的な 配向性によることは明らかである。こうした微小欠陥構 造がどの時期にいかにして形成されたかという問題につ

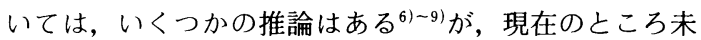
解明の部分が多く残されている. しかしながら，これら の欠陥構造が選択的な配向性を有するという事実は注目 に值する．すなわち，Plumb ら゙が述べているように微 小欠樎構造の卓越する方向が局所的なものでなく，かな り広い範囲にわたって優先的な方向性を有するのであれ ば，これらの欠陥構造は地殼における過去の応力履歴を 反映していると考えられるので，これらの久陥構造の方 向性を明らかにし，その成因について検討することは， 岩盤内の初期応力の測定などとも関連して, 岩盤力学的 な立場からも重要なことである. 現在, 岩盤内構造物の 設計資料を得るため，あるいは地震予知のための基礎的 研究を主目的にして, 測地学的な方法 ${ }^{10)}$, 応力解放法 ${ }^{111}$, 水生破砕法 ${ }^{12)}$, 活断層による方法 ${ }^{13)}$, 地震学的な方法 ${ }^{14)}$ など, 種々の地殸や岩盤内の応力測定法が提案され注目 すべき結論が得られつつある．しかしながら一方で各測 定方法は固有の欠点や改良すべき点を残しており，必ず しも各測定結果が一致しているとはいいがたい占．こう した点を考慮すれば，各測定方法による相補的なデー夕 の活用を考えるべきであろう．本研究では，まず調査地 域として瀬戸内地方を設定した。この地方は，たとえば 測地学的な方法では一定の傾向が認められておらず，ま た活断層による方法では空白域を形成している地域であ り調査の意義は大きいと考えられる.

\section{2. 瀬戸内地方の花崗岩質岩石の異方性}

本研究では花崗岩質岩石の異方性の地域特性を明らか にするため, 黒髪島から小豆島にいたる瀬戸内地方中央

注 3）造岩鉱物内のクラックは，大別すると開口したクラッ ク (open crack) と㥶着して液体包有物 (liquid inclusion) が面状に集合した「クラック」に分類される.ここでは 前者をクラック，後者を液粒面 (liquid inclusion plane または bubble track) とよぶ。
部にいくつかの調査地点を設定し, 原位置における花崗 岩質岩石の石目の方向に関する調查, 岩石供試体による 弾性波速度 $\left(V_{\rho}\right)$ 試験および岩石薄片の観察を行う。そ してこの結果をもとに瀬戸内地方での花崗岩質岩石内の 微小久陷構造の選択的な配向性について検討する.

この地域は地質学的な分類からすれば西南日本内帯に 属し, 花崗岩質岩石は領家帯の花崗岩質岩石之中国帯の 岩石に分類される.このうち中国帯の花崗岩質岩石のほ とんどは広島花崗岩帯に属している．調查地点の選定に あたっては，風化作用などによる欠樎構造と区別するた め新鮮な露頭が存在することを第一の要件とした．さら に洗練された石工職人の石目を識別する能力 ${ }^{16)}$ を参考に するため,こうした職人の存在も考慮した.このことは, 石目に関する情報が本研究を進めるうえで有用となり得 ると考えたからである. 本研究では，こうした採石場の 石材用の岩石のみを取り扱っている。このためたとえば 山口県東部にみられるような片麻状花崗岩は, 石材用の 岩石として不適当であるという理由だけで省かれてい る.さらに同じ地域であっても採石場ごとに造岩鉱物の 粒形や「割れやすさ」の程度が異なるため，できるだけ 同じ地域に複数の測定点を設定した。

\section{（1）石目の走行と傾斜}

石目の方向の測定は，採石場における石工職人の経験 則を基本にしており，採石場に石目に沿う壁面が露出し ている場合には，原位置でその壁面の走行および傾斜角 を測定した。またこうした壁面がない場合は，できるだ け直交関係になるような複数の壁面で，石目の方向を記 入し，計算により三次元的な位置関係を明らかにした。 走行角の記載にあたっては，偏角補正を行っている.

調查結果（付録参照）から, rift plane の走行, 傾斜 が明らかなもののみを選択してシュミット網に整理した のが図一1である．図からまず明らかなことは，香川県 青木島の一例（図中 C-2）を除けば瀬戸内地域におけ る rift plane の方向がほぼ水平面に近いということであ る. 調查地点が瀬戸内地域のほぼ全域を網羅しているこ

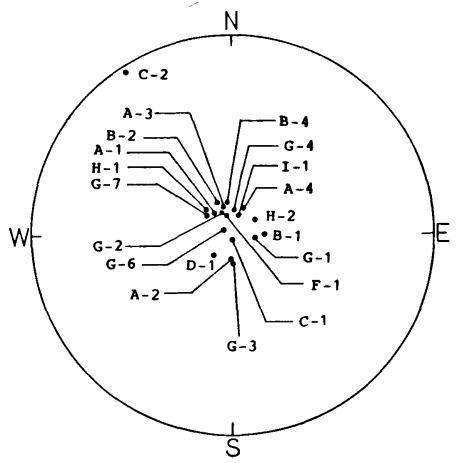

図一1 瀬戸内地方の rift plane のシュミット投影 


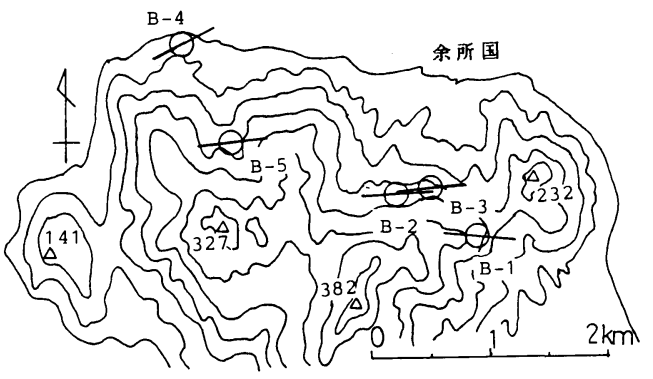

（a）大島

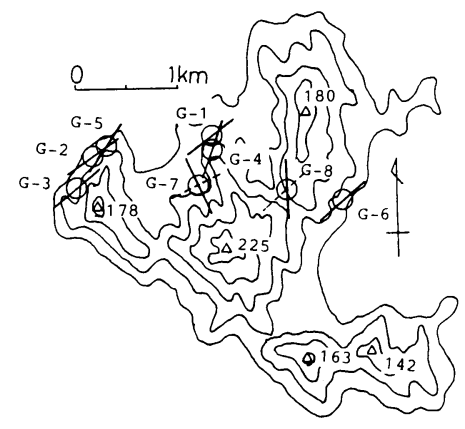

（b）北槝

図一2 大島，北槝における grain plane の走行

とから考えれば，このことは瀬戸内地方の一般的な特性 であるということが推察できる.

grain plane が優先的な方向性を有するかどうかとい う問題は石目を構成する久陥構造の成因の問題などと関 連して特に重要である. 岡村 ${ }^{17)}$ が黒髪島産の岩石につい て行った石目の方向に関する調查結果では, grain plane は優先的な方向性を有していない.これに対して， Plumb ら ${ }^{4)}$ は New England の花崗岩について，広い範 囲 $(300 \mathrm{~km}$ 程度) を統計的に解析すれば, 先在クラッ クの方向が優先的な方向性をもつことを指摘している. ここで grain plane の地域的特性を詳しくみるために， 大島 (図一6 6 B), 北木島 (図一のG) の調査結果に ついて検討する.この地域の採石場においてはgrain plane の傾斜はほぼ鉛直に等しいので, 走行のみを示し たものが図一2である. 図中の○は, rift plane がほぼ 水平であることを示す. 大島については, 地形とほとん ビ関係なく，いずれの採石場でも $\mathrm{N} 80^{\circ} \mathrm{E} \sim \mathrm{EW}$ (一部で $\left.\mathrm{N} 65^{\circ} \mathrm{E}\right)$ の走行が卓越していることが認められる. ま た北木島でも, 測定された 8 地点の調查地点のうち, 6 地点までが $\mathrm{N} 50^{\circ} \mathrm{E}$ 近傍の走行が卓越しており, 2 地点 のみ NS 系の走行が卓越している.このことは, 今回調 査した半径 $2 \sim 3 \mathrm{~km}$ 程度の小地質区分内では, 石目の

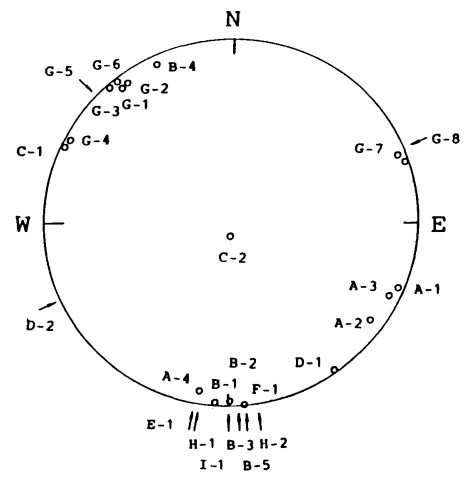

図一-3 瀬戸内地方の grain plane のシュミット投影
方向がきわめて類似した傾向をもつことを示している. 次に, 瀬戸内地域における grain plane の大まかな傾 向をみるために, grain plane の走行, 傾斜が明らかな 採石場についてシュミット網に整理した結果を図一3に 示す. 図一1に示すように rift plane はほぼ水平であり これに直交する grain plane はほぼ鉛直面となる。そこ で grain plane の傾斜が明らかでない調查地点について は，図の外に矢印で走行を示してある．図より EW お よび NE-SW の走行が卓越しており, 瀬戸内地方とい う比較的広い範囲で考えた場合も, 石目が卓越した方向 を有していることが認められる.

ここで, 青木島産の花崗閃緑岩は図一1および図一3 においてその傾向が例外となっている.この岩石は最も 割れやすい面がほぼ垂直，次に割れやすい面がほぼ水平 である．著者らはこれを慣用上 rift plane, grain plane と統一してよんでいるものであり，その順序は割れやす さ以外の意味を有していない.たまたま他の岩石とは逆 に水平方向より垂直方向により割れやすい面が形成され たとすればこの例外はなくなる.

\section{（2）弾性波速度試験}

これまでに述べてきた手法は，採石場における経験則 に着目して, 花崗岩質岩石内の欠陥構造に関する大まか な特性を記述することにあった.しかしながら，この方 法は経験則に依拠したものであり, 微小欠陷構造につい て検討する前に，この方法の有効性を確認し，さらに rift plane, grain plane, hardway plane の各面の発達 程度の検討を行う必要がある.このために測定が比較的 容易で非破壊的に検討が可能な弾性波伝播速度 $\left(V_{p}\right)$ を 測定した. $V_{p}$ は, 微小欠陷構造の中でも, 開口したクラッ クの存在に対して敏感であり ${ }^{18)}$ ，これらのクラックによ る影響を比較する際に有効である. 用いた供試体の直径 は約 $43 \mathrm{~mm}$ である．測定にあたっては，石目に垂直な 方向に抜き取られた試料の半径方向に測定径路を設定 し, 試料の直径と, これを弾性波が伝播するに要する時 

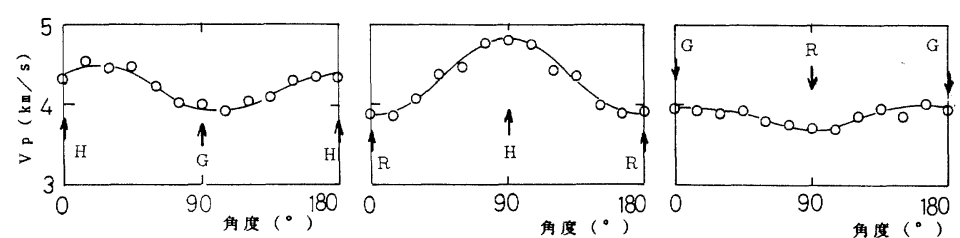

(a) 合棈島花徼岩
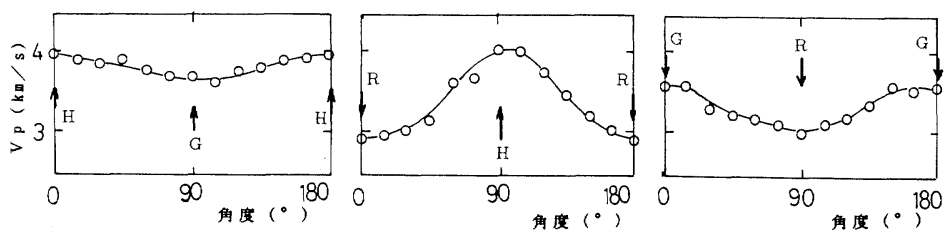

(b) 北木岛花尚岩

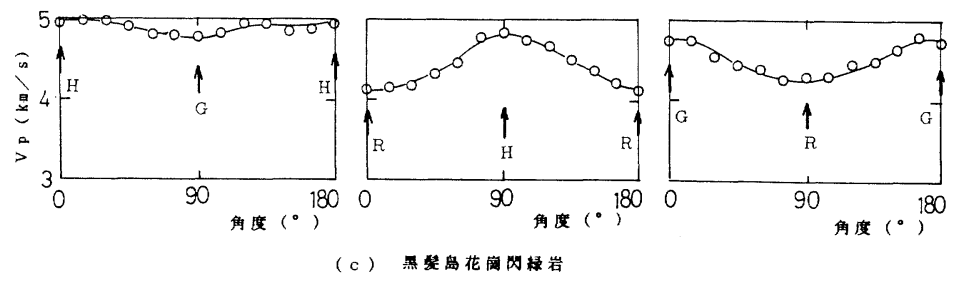

図一－弾性波速度 $\left(V_{p}\right)$ の異方性

( R, G, H は，波動の進行方向がそれぞれ rift plane, grain plane, hardway plane に垂直であることを示す

間から $V_{p}$ の值を決定した．測定はすべて気乾状態で行 われている.

すべての地域に対して得られた $V_{\rho}$ の測定結果の中か ら代表的なものを 3 組選んで図一 4 に示す. 図中 $0^{\circ} お$ よび $90^{\circ}$ は採石場で判定された石目の方向と一致してい る。これらの図からまず明らかなことは，大まかにみて rift plane に垂直に進行する波動，grain plane に垂直に 進行する波動, hardway plane に垂直に進行する波動が この順に最小, 中間, 最大の速度になるという点である.

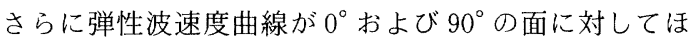
ぼ対称性を有しているのも共通した特徴である。このこ とはこれらのすべての岩石がほぼ直交異方性を有するこ と，さらに採石場で判定された石目の方向がほぼ岩石内 の欠陥構造の方向と一致していることを示すものであ

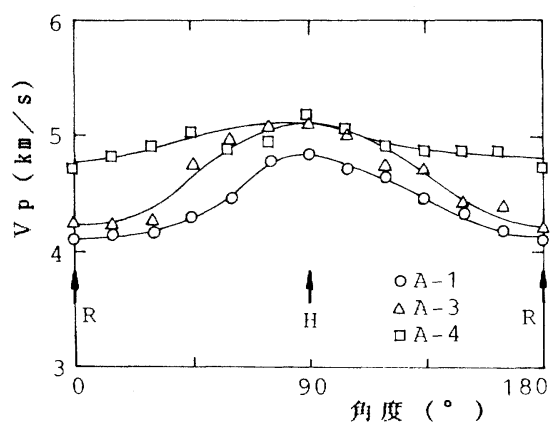

図一5 黒髮島花崗閃緑岩の弾性波速度の異方性
る.

ここでそれぞれの岩石の異方性の発達の程度を検討す る. 倉橋島花崗岩の場合は, grain plane に垂直に進行 する波動が hardway plane よりむしろ rift plane に垂直 に進行する波動の速度に近い。したがって, rift plane および grain plane のクラックが同程度によく発達して いるということを示唆している．これに対して，黒髪島 花崗岩では, rift plane に垂直に進行する波動のみが大 きく減少し，grain plane がむしろ hardway plane に近 いような特性を示している。このことは, rift plane の クラックのみがよく発達していることに対応するもので あろう。これに対して北木島産の花崗岩では, grain plane に垂直な方向の速度は rift plane と hardway plane に垂直な方向の速度の中間的な值となっており，

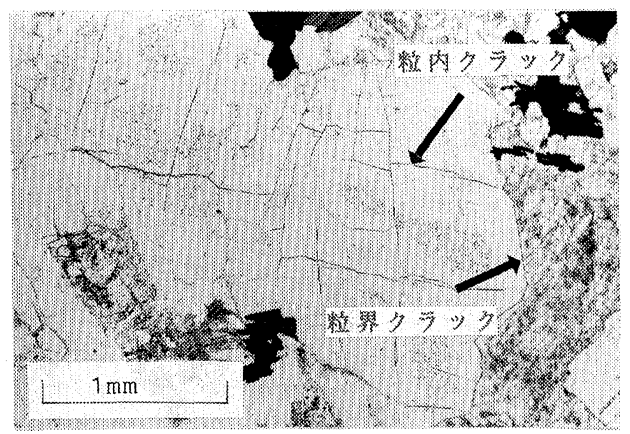

写真一1 粒内クラックと粒界クラック（北木島花崗岩） 


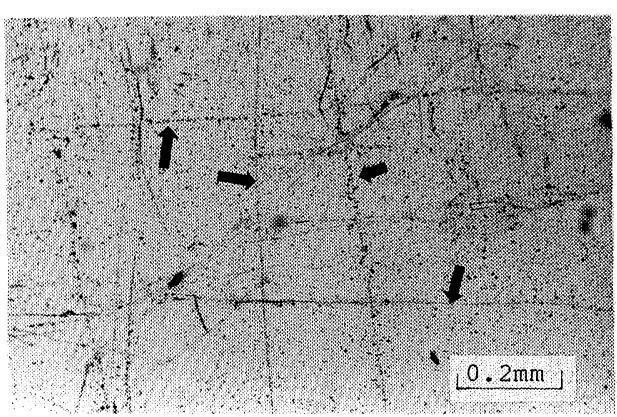

（a）石英内の液粒面（北木島花崗岩）

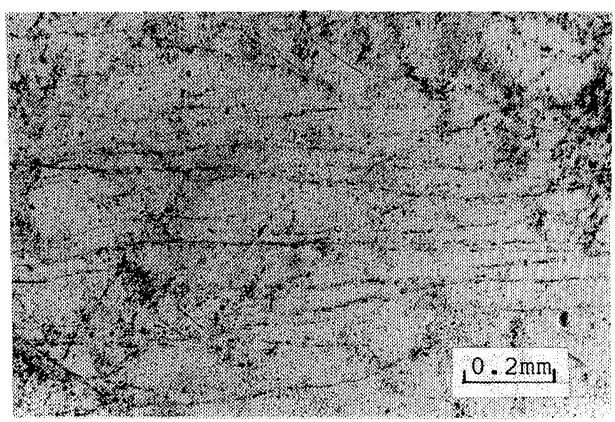

（b）長石内の液粒面（倉橋島花崗岩）

写真一2 液粒面

grain plane が中程度に発達していることが推察される.

次に局所的な領域内での $V_{p}$ の変動について調べるた め, 黒髪島の近接する 3 加所の採石場から得られた岩石 供試体について, 速度異方性が最も大きく現われる grain plane に平行な面の $V_{p}$ を測定した結果を図一 5 に 示す.これらの岩石で hardway plane に垂直に伝播す る $V_{p}$ の值はほぼ等しいものの, rift plane に垂直に伝 播する $V_{p}$ の值はかなり異なっている．すなわち異方性 の発達の程度は近接した地域でもかなり異なっており, このことはクラックの発達程度に局所的な原因, たとえ ば応力場が影響を与えていることを示唆している.

\section{（3）花崗岩質岩石内の微小欠陥構造}

これまで弾性波速度試験の結果などから岩石の内部構 造について推定してきたが,これらの内部構造を直接観 察することは, 花崗岩質岩石の異方性を検討していくう えで重要である. 岩石の内部構造を直接に観察する代表 的な方法として光学顕微鏡による方法, 走査型電子顕微 鏡による方法 ${ }^{19}$, 透過型電子顕微鏡による方法 ${ }^{20)}$ なビが あり, それらはまたいくつかの方法に分類される. 本研 究では, 花崗岩質岩石を構成する造岩鉱物の粒径が比較 的大きいこと，そのために観察に広い視野を必要とする
こと,さらに岩石組織との関連で議論する際に有効であ るという理由から偏光顕微鏡による観察を行った．採石 場で基本的な方向を記載した岩石について, 観察面がそ れぞれ石目の方向と平行になるように,かつ薄片の長辺， 短辺方向が石目の方向と一致するように薄片を作製し た.すなわち 1 つの岩石につき 3 個の薄片が作製される. 薄片の厚さは約 $2 / 100 \mathrm{~mm}$ である.

ここでは薄片の観察によって微小欠陥構造の存在様式 を岩石組織との関連で明らかにすることを主目的にして いる. 花崗岩質岩石の異方性を特徵づける久陥構造には いくつか考えられるが, なかでも花崗岩質岩石の異方性 に大きく寄与する欠陥構造と考えられるクラックと液粒 面を取り上げた. さらに，クラックについては写真一1 に示すような粒内クラックと粒界クラックに分類した. 粒界クラックについても異方性が認められるという報告 もある ${ }^{211}$ が, その程度は小さいと考えられるので, 本研 究では主に粒内クラックについて検討した. また石英粒 内から長石内に伸張するクラックもしばしば認められる が, これらは石英内のクラックとして処理している. 液 粒面については, 写真一2に示すように, 石英内の液粒 面と長石内の液粒面に分類した.

\section{表一1 花崗岩質岩石の石目を特徴づける微小欠陥構造}

\begin{tabular}{|c|c|c|c|c|c|}
\hline 記 号 & 産 地 & 岩 石 名 & rift plane & grain plane & hardway plane \\
\hline$A$ & 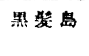 & 花阙閃粶崔 & クラック（石萁） & $\begin{array}{l}\text { クラック (否英) } \\
\text { +液粒面（英） }\end{array}$ & クラック (功苑) \\
\hline$B$ & 大帛 & 花阙閶粶岩 & クラック(石英) & $\begin{array}{l}\text { クラック (石英) } \\
\text { +液粒预 (石英) }\end{array}$ & 液粒䤄（舞矿） \\
\hline $\mathrm{C}$ & 青木岛 & 花耑閃粶岩 & $\begin{array}{l}\text { クラック（石英） } \\
\text { 十液精面（石英） }\end{array}$ & クラック（石英） & クラック（石英） \\
\hline$D$ & 庵治 & 花闵岩 & $\begin{array}{l}\text { クラック（石英） } \\
\text { 十液粒面(石英) }\end{array}$ & $\begin{array}{l}\text { クラック（石烡） } \\
\text { +液粒面（石英） }\end{array}$ & $\begin{array}{l}ク \text { ク只(石英) } \\
+ \text { 湾粒面（石英） }\end{array}$ \\
\hline$E$ & 倉橋島 & 花筒岩 & クラック（石英） & $\begin{array}{l}\text { クラック（石英） } \\
\text { +被粒面（石英） }\end{array}$ & $\begin{array}{l}\text { 液粒面（長石） } \\
+ \text { 液粒面（石英） }\end{array}$ \\
\hline $\mathrm{F}$ & 赤坂 & 花廚岩 & クラック（石英） & 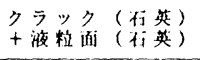 & 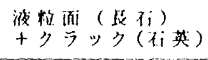 \\
\hline G & 北木島 & 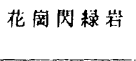 & クラック（石英） & 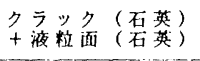 & 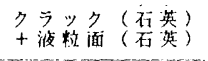 \\
\hline$H$ & 万成 & 花阙岩 & クラック（石英） & $\begin{array}{l}\text { クラック（砛英） } \\
+ \text { 液粒面（石英） }\end{array}$ & 特になし \\
\hline
\end{tabular}




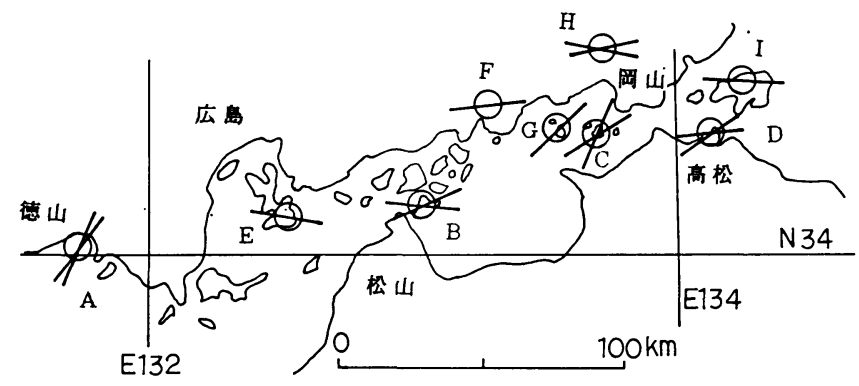

図一6石英内の微小欠陥構造の配向面の走行

最初に, 各地域ごとに微小欠陥構造がどのような形で 存在するかを調べるために，まず北杰島および大島産の 岩石内の欠陥構造について, それぞれ 8 か所および 4 か 所の採石場の岩石の薄片を作製し検討した．その結果， それぞれの地域での各面内の欠樎構造は各薄片内でほぼ 同じ傾向を示すことが見出された。すなわち北木島では rift plane, grain plane および hardway plane の順に, 石英内のクラック, 石英内のクラックと液粒面の共存, 石英内のクラックと液粒面さらにはカリ長石内のパー ティングが選択的に配向している.さらに図一2(b) で, grain plane の方向が島の支配的な grain plane の方向か

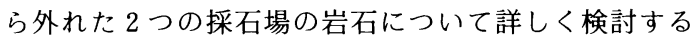
と, いずれの岩石についても grain plane とは別の方向 に微小欠陥構造の選択的配向面を有することが認められ る.これらのうちの $1 つ$ (付録 G-8) は grain plane と 斜交しており，他の $1 つ （$ 付録 G-7）は grain planeに ほぼ直交している。これを示したのが, 図一2(b) の破 線である. 破線の方向は, 北木島の支配的な grain plane の方向と一致する.すなわち島内のほぼ鉛直方向 に選択的に配向する微小欠陥構造の方向はもともと同じ 方向で, 局所的な条件下で現在のようなクラックが形成 されたと考えられる.また大島産の岩石では, rift plane および grain plane はほぼ同様であるが, hardway plane では長石内の液粒面の選択的配向性が支配的 であることが認められた。 また他の地域の岩石について も, 裸眼での観察や $V_{p}$ の計測によって rift plane の欠 陥構造は石英内のクラックによることが認められた。 以 上のことから他地域の岩石の調査に際しては薄片観察は 各地域それぞれ 1 か所の岩石に限ることとし, grain plane および hardway plane を特徵づける欠陥構造を主 として検討した。

こうして各地域の石目を特徵づける微小久陥構造につ いて, 微小久陥構造の種類とそれが存在する造岩鉱物に ついて分類したのが表一1である. 弾性波速度試験の結 果からも推測されたように, ほとんどの岩石で, rift plane は石英粒内の開口したクラックが支配的な役割を
果たしており, grain plane についても石英粒内のクラッ クあるいは石英粒内の液粒面により特徴づけられてい る.さらに hardway plane を支配する欠陥構造は, 石 英粒内のクラック, 石英粒内の液粒面, 長石粒内の液粒 面およびパーティングと多様である. 特に液粒面につい ては,一般にクラックよりも古期の欠陥構造と考えられ, こうした欠陥構造の起源や応力の履歴を検討する際には 重要であると考えられる.

\section{3. 微小欠陥構造の方向性からみた岩盤の異方 性に関する検討}

これまで述べてきた rift plane や grain planeなど石 目に関する表現は, 採石場における用語を踏襲したもの であり, 原位置応力などとの関連で議論する場合は, こ れまで示した測定結果をこうした立場から整理しておく 必要がある. 多くの測定結果が示すように, 日本列島の 地壳内の最大圧縮応力の方向は土木構造物の対象となる

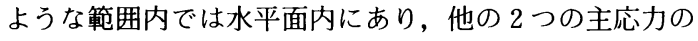
1 つが鉛直方向である ${ }^{22}$. このことはこれまで述べてき た石目に関する調査結果と調和的である. そのためこの 応力場に対応させてこれまで述べてきた微小久陥構造 を, ほぼ水平に発達した欠陥構造とほぼ鉛直に発達した 欠陥構造に分類して検討することにする. また石英粒内 の液粒面については，一般にクラックが療着した構造と 考えられており, 以下クラックとして扱う.これらを整 理して地図上に示したのが図一6である. 図中の○印は, ほぼ水平面内に石英粒内クラックが選択的に配向してい ることを示す. 図は前に述べた石目に関する測定結果や 薄片の観察結果から, 同一地域で支配的な方向の見出さ れる地域 (北木島, 大島, 黒髪島)については, その平 均の方向を, そうでない地域については逐一その方向を 記入したものである. 図より瀬戸内地方の花崗岩質岩石 は例外なくほぼ水平面内に選択的に配向する欠樎構造を 有し, 表一1 とも併せて考えるとこれらは石英粒内のク ラックあるいは石英粒内の液粒面によるということがわ かる. さらに鉛直方向に選択的に配向する欠陥構造のう 


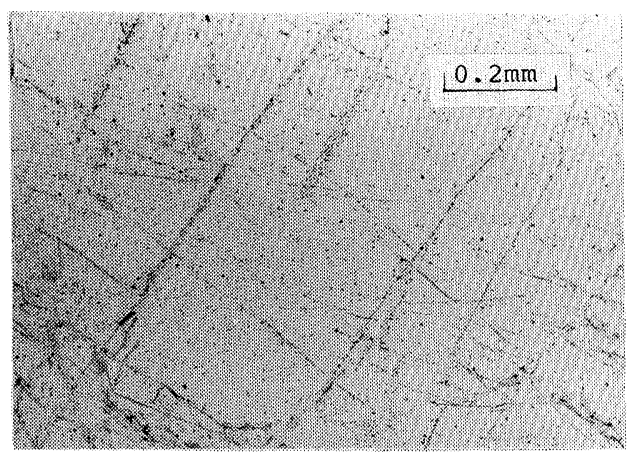

写真一3 水平面内のクラック（長辺）に斜交する液粒面

ち, 石英内のクラックによって支配される面の走行は, 若干地域的な差異は認められるものの EW と NE-SW の方向に卓越している.

次に，鉛直面内に選択的に配向する欠陥構造のうち， 長石内の液粒面によって特徴づけられる面について述べ る. 表一1 からも明らかなように大島産の花崗閃緑岩, 倉橋島産および赤坂産の花崗岩には鉛直面内に長石粒内 の液粒面の選択的な配向性が認められる。これらの液粒 面は, カリ長石と斜長石の粒界では連続して分布するが， 石英との粒界では停止し, 石英粒内に伸張することはな い. また液粒面の密度は，たとえば大島産の場合は 1 $\mathrm{mm}$ 中に約 100 個というようなきわめて高い密度で存在 している. さらに薄片面をこれらの液粒面と一致させた 場合, 写真一3に示すような, 石英粒内に開口したクラッ クの系と斜交する他の直交する液粒面の系が認められ る.これら液粒面の系は薄片面に垂直である.すなわち 石英粒が結晶後に少なくとも 2 回の異なる応力履歴を受 けたことが推察され, その際液粒面に垂直な軸を中心に 回転していることがわかる. 長石内の欠陷構造が液粒面 であることを考えると, 現在の rift plane および grain plane より古い欠陷構造であることを示している. Tuttle ${ }^{6)}$ は, 液粒面の生成・発達過程を，1）石英粒内 での微小クラックの生成と流体による充填，2）珪酸の 選択的溶融之沈殿によるシート状構造の形成，3）引続 く溶融・沈殿による液粒面の発達による球状の液体包有 物による液粒面の形成, という発達段階で示し, 液体包 有物の発達の程度を観察することによって生成年代に関

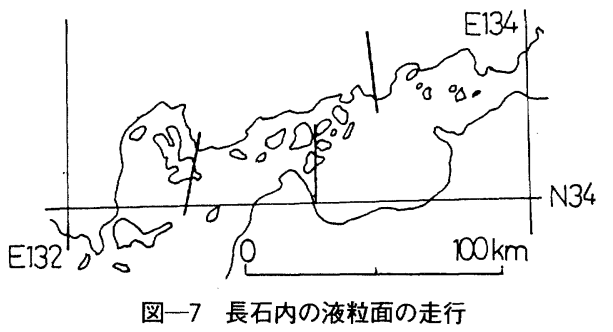

する相対的な評価が可能であることを示している．石英 と長石という造岩鉱物の相違はあるが，長石内で観察さ れる液粒面が石英粒内のものに対して包有物も微細でよ く発達している.このことは長石粒内の液粒面が石英粒 内のクラックなどに比べて古期のものであるということ を示すものであると考えられる。これらの地域における 長石粒内の液粒面の方向を hardway plane の方向を参 照して示したのが図一7である. 図よりこれら液粒面が ほぼ南北の方向となっており, 花崗岩質岩石内の微小欠 陷構造の古期のものがこの方向に対応した応力場によっ て形成されたことを示唆している.

\section{4. おわりに}

本研究では瀬戸内地方における花崗岩質岩石の石目の 方向を調査することによってこれらの岩石の力学的異方 性の主軸を明らかにしてきた. 本研究で採石場の岩石を 取り上げたのは, 採石場に新鮮な露頭が存在し, 微小欠 陥構造を研究する際に著しく好都合だという積極的な理 由によるものである.こうしたテーマについては，わが 国ではほとんど調査の事例がなく, したがってその手法 も確立されていない。 そのため研究手法として, まず小 地質区分においてはこれらの微小久陷構造の方向性につ いて共通した特徴が認められることを述べて, 調査地点 を瀬戸内地方に拡大していくという手法をとった. 調查 地点については統計的に解析するに十分な数が望ましい が, そうした調査は現時点ではきわめて困難であるため, 現在稼業中の採石場についてできるだけ多く測定点を設 けるように努めた．すでに述べてきたように，瀬戸内地 方という広い範囲で考えた場合も, いくつかの重要な点 で共通した特徴が認められ, 本研究で得られた結論が採 石場の岩石に固有の性質であるとは考えがたい. 事実本 研究では瀬戸内地方の代表的な花崗岩体を網羅してお り，これらの花崗岩体の広い範囲にわたる連続性と花崗 岩質岩石内の微小欠陥構造の規則性を考慮すれば,ここ での結論が少なくとも調查地域内では一般性を有してい ると考えられる.

本研究により得られた結論を列挙すれば以下のとおり である。

（1）花崗岩質岩石内の微小欠陥構造の方向は同一地 域内ではかなり類似した傾向を示す.さらに力学的異方 性の程度はこうした地域内でも局所的にかなり変動する が，岩石内の欠陥構造は同質のものであることが明らか になった。

（2）調査したすべての地域で, 石英内の開口したク ラックおよび場所によっては液粒面によって特徴づけら れる欠陷構造が, 例外なくほぼ水平に発達していること が認められた.このことは, 瀬戸内地方の一般的特徴之 
考えられる.

（３）瀬戸内地方の花崗岩質岩石にはほぼ直交する 2 つの微小久陷構造が鉛直方向にも発達している.このう ち石英内のクラックあるいは石英粒内の液粒面によって

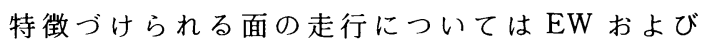
NE-SW が卓越している.

（4）ほぼ鉛直方向に配向した他の 1 つの欠陥構造 は, 必ずしも特定できないが, 長石粒内の液粒面が発達 しているものが多い.

以上, 本研究で明らかにされた瀬戸内地域における花 崗岩質岩石の微小欠陥構造の特性とその選択的配向性 は, 原位置における応力測定やこの地域における地壳応 力場の解析に対して基礎的な資料を提供するものと考え ている. しかしながら, 瀬戸内地方の花崗岩質岩石内の 欠陥構造のこうした特徵が日本列島全体に対して一般性 をもち得ないことに留意する必要がある，たとえば，東 北日本弧の花崗岩質岩石の主な採石場では, rift plane や grain plane が水平面と一致しない年. すなわち水平 面に沿う石英内のクラックの選択的な配向性は認められ ないか, 認められたとしても瀬戸内地方の岩石に比べて 密度が小さい。これらのより広域的な微小久陷構造の特 性については日本列島全体の地殼構造との関連で解釈す べき多くの問題を含んでいると考えられ，その解明につ いては今後の課題としたい.

本研究を進めるにあたり, 広島大学名誉教授 小島丈 兒先生には影微鏡の観察方法について懇切なご指導をい ただいた。徳山高専技官 山本秀喜氏, 卒研生の徳本耕 嗣君（広島道路エンジニア）および内木博信君（西松建
設）には，コアボウリングや弾性波速度の測定で協力を お願いした．さらに，黒髪石材（株）をはじめとする瀬 戸内沿岸の石材業者および石工職人の方々には調査活動 に多大なご協力をいただいた．記して謝意を表する.

\section{参 考 文 献}

1) Dale, T. N. : The Commercial granite of New England, Bull. U.S. Geol. Surv. 738, pp. 22 103, 1923.

2) Osborne, F.F. : Rift, grain and hardway in some PreCambrian granites, Quebec, Econ. Geol., 30, pp.540 551, 1935.

3) Balk, R. : Structural behavior of igneous rock, Geol. Soc. Amer. Mem. 5, 1937.

4) Plumb, R., Engelder, T. and Yale, D. : Near surface in situ stress : 3 Correlation with microcrack fabric within the New Hampshire Granite, J. Geophys. Res., Vol. 89, No. B11, pp. 9350 9364, 1984.

5）工藤洋三・橋本堅一・佐野 修・中川浩二：花崗岩の力 学的異方性と岩石組織欠陥の分布, 土木学会論文集, 第 370 号, III-6, pp. 189 198, 1986.

6) Tuttle, O.F. : Structural petrology of planes of fluid inclusions, J. Geol., 57, pp. 331 356, 1949.

7) Todd, T., Simmons, G. and Baldridge, W. S. : Acoustic double refraction in low-porosity rocks, Bull. Seismol. Soc. Amer., 63, pp. 2007 2020, 1973.

8) Nur, A. and Simmons, G. : The origin of small cracks in igneous rock, Int. J. Rock Mech. Min. Sci., 7, pp. 307 $\sim 314,1970$.

9) Richter, D. and Simmons, G. : Microcracks in crustal igneous rocks : microscopy. In : J.G. Heacock (Editors), The Earth's Crust. Amer. Geophys. Union, Geophys. Monogr., 20, pp. 149 180, 1977.

付録 花崗岩質岩石採石場における石目の配向

\begin{tabular}{|c|c|c|c|c|c|c|c|}
\hline No & & 記 号 & 産 地 & 所 在 地 & rift plane & grain plane & 借考（塖石场名等） \\
\hline $\begin{array}{l}1 \\
2 \\
3 \\
4\end{array}$ & $\begin{array}{l}\text { 領 } \\
\text { 家 }\end{array}$ & $\begin{array}{l}A-1 \\
A-2 \\
A-3 \\
A-4\end{array}$ & 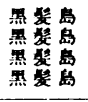 & 山口具彭山市 & $\begin{array}{l}N 49^{\circ} \mathrm{E} 11^{\circ} \mathrm{W} \\
N 88^{\circ} \mathrm{K} 11^{\circ} \mathrm{W} \\
N 72^{\circ} \mathrm{E} 11^{\circ} \mathrm{W} \\
N 65^{\circ} \mathrm{N1} 1^{\circ} \mathrm{W}\end{array}$ & 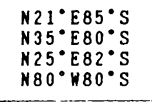 & 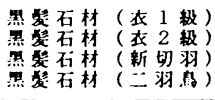 \\
\hline $\begin{array}{l}5 \\
6 \\
7 \\
8 \\
9\end{array}$ & $\begin{array}{l}\text { 带 } \\
\text { 花 } \\
\text { 阙 }\end{array}$ & $\begin{array}{l}B-1 \\
B-2 \\
B-3 \\
B-4 \\
B-5\end{array}$ & $\begin{array}{l}\text { 大岛 } \\
\text { 大岛 } \\
\text { 大峋 } \\
\text { 大岛 } \\
\text { 大岛 }\end{array}$ & 爱媛紧㝠理 & $\begin{array}{l}\text { NS } 13^{\circ} \mathrm{E} \\
N 65^{\circ} \mathrm{E} 14^{\circ} N \\
\text { ほ } \\
\text { N8 } 80^{\circ} \mathrm{E} 12^{\circ} N \\
\text { ほ }\end{array}$ & $\begin{array}{l}\text { N85 } 887^{\circ} \mathrm{S} \\
\mathrm{E} H 85^{\circ} \mathrm{S} \\
\mathrm{N} 87^{\circ} \mathrm{E} \\
\mathrm{N} 65^{\circ} \mathrm{E} 83^{\circ} \mathrm{N} \\
\mathrm{N} 85^{\circ} \mathrm{E}\end{array}$ & $\begin{array}{l}\text { 浩成石材 } \\
\text { 山晒石材 } \\
\text { 小田石材 } \\
\text { 魯瀬石材 } \\
\text { 双葉石材 }\end{array}$ \\
\hline $\begin{array}{l}10 \\
11\end{array}$ & 岩 & $\begin{array}{l}C-1 \\
C-2\end{array}$ & $\begin{array}{l}\text { 青木島 } \\
\text { 声木忽 }\end{array}$ & 香川缜丸奄市 & $\begin{array}{l}N 10^{\circ} \mathrm{E} 2^{\circ} \mathrm{S} \\
\mathrm{N} 57^{\circ} \mathrm{E} 88^{\circ} \mathrm{N}\end{array}$ & $\begin{array}{l}N 25^{\circ} E 88^{\circ} W \\
N 88^{\circ} \mathrm{Y} 5^{\circ} W\end{array}$ & 金渏石材 \\
\hline $\begin{array}{l}12 \\
13\end{array}$ & & $\begin{array}{l}D-1 \\
D-2\end{array}$ & $\begin{array}{l}\text { 魔治 } \\
\text { 虐治 }\end{array}$ & 要川㩆籍治町 & $\begin{array}{l}N 50^{\circ} \mathrm{W1} 1^{\circ} \mathrm{S} \\
\text { はほ水平 }\end{array}$ & $\begin{array}{l}N 55^{\circ} \mathrm{E} 88^{\circ} \mathrm{S} \\
\mathrm{N} 82^{\circ} \mathrm{E}\end{array}$ & 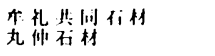 \\
\hline 14 & & $E-1$ & 倉㭻岛 & 広岛県倉橋町 & ほほ水平 & $N 79^{\circ} \mathrm{W}$ & 受石材 \\
\hline 15 & 中 & $F-1$ & 福山 & 広帛惧䙅山市 & $\mathrm{N} 87^{\circ} \mathrm{W} 10^{\circ} \mathrm{K}$ & $N 85^{\circ} \mathrm{E} 83^{\circ} \mathrm{N}$ & 伊垣不材 \\
\hline $\begin{array}{l}16 \\
17 \\
18 \\
19 \\
20 \\
21 \\
22 \\
23\end{array}$ & $\begin{array}{l}\text { 国 } \\
\text { 带 } \\
\text { 花 } \\
\text { 崗 }\end{array}$ & $\begin{array}{l}G-1 \\
G-2 \\
G-3 \\
G-4 \\
G-5 \\
G-6 \\
G-7 \\
G-8\end{array}$ & 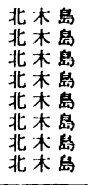 & 岡山牂笠岡市 & 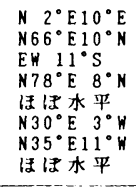 & 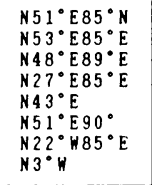 & 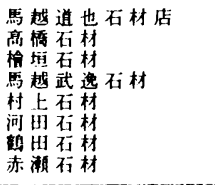 \\
\hline $\begin{array}{l}24 \\
25\end{array}$ & 類 & $\begin{array}{l}H-1 \\
H-2\end{array}$ & $\begin{array}{l}\text { 万戊 } \\
\text { 少成 }\end{array}$ & 岡山䀥咸山市 & $\begin{array}{l}\mathrm{N} 39^{\circ} \mathrm{E} 13^{\circ} \mathrm{W} \\
\mathrm{N} 30^{\circ} \mathrm{W} 11^{\circ} \mathrm{E}\end{array}$ & $\begin{array}{l}N 81^{\circ} \mathrm{W} \\
\mathrm{N} 81^{\circ} \mathrm{E}\end{array}$ & 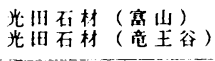 \\
\hline 26 & & $1-1$ & 小互岛 & 香川累小豆郡 & $N 77^{\circ} \mathrm{W} 8^{\circ} \mathrm{N}$ & EW & 中增石材 \\
\hline
\end{tabular}


10）たとえば，原田健久・葛西篤男：最近 60 年間における日 本の地款の水平歪, 測地学会誌, 第 17 巻, 第 1,2 号, pp. 4〜7, 1971.

11) たとえば, Merrill, R.H. and Peterson, J.R. : Deformation of a borehole in rock, Rep. Invest. U.S. Bur. Mines, 5881, 32 p., 1961.

12) たとえば, Hubbert, M. K. and Willis, D. G. : Mechanics of hydraulic fracturing, Transactions AIME, Vol. 210, pp. 153 168, 1957.

13）たとえば, 岡田篤正・安藤雅孝 : 日本の活断層と地震, 科学, Vol.49, No. 3, pp. 158 169, 1979.

14）市川政治：日本付近の地震のメカニズムに関する統計的 研究と二, 三の問題, 気象庁研究時報, 第 18 巻, 第 2 号, pp. 83〜154, 1966.

15）小出 仁ほか：関東・東海地域における地殼応力測定と 測定法の比較, 第 18 回岩盤力学に関するシンポジウム講 演論文集, pp. $261 \sim 265,1986$.

16）工藤洋三・橋本堅一・佐野 修・中川浩二：石工の経験 則と花崗岩の力学的性質, 土と基礎, Vol. 34 , No. 8, pp. $47 \sim 51,1986$.

17）岡村義彦: 山口県徳山市黒髪島花崗岩体の構造, 広島大
学地学研究報告, 第 14 号, pp. 307 316, 1965.

18）工藤洋三・橋本堅一・中川浩二 : 花崗岩質岩石の力学的 異方性と内部欠陷構造, 土質工学研究発表会, 1986.

19）たとえば, Sprunt, E. and Brace, W.F. : Direct observation of microcavities in crystalline rocks, Int. J. Rock Mech. Min. Sci., 11, pp. 139 150, 1974.

20）たとえば, Boland, J. N. and Hobbs, B. E. : Microfracturing processes in experimentally deformed peridotite, Int. J. Rock Mech. Min. Sci., 10, pp. 623 626, 1973.

21) Peng, S. S. and Johnson, A. M. : Crack growth and faulting in cylindrical specimens of Chelmsford granite, Int. J. Rock. Mech. Min. Sci., 9, pp. 37 86, 1972.

22）土木学会編：土木技術者のための岩盤力学, pp. 43〜 46, 1975.

23）工藤洋三・橋本堅一・佐野 修・中川浩二：花崗岩採石 場における石目の配向に関する調查, 第 16 回岩盤力学に 関するシンポジウム論文集, pp. 290〜293， 1984.

(1986.5.30 - 受付) 